
Yil 15
Güz 2017
Sayı 23
Ss. 247-264

Geliş Tarihi: 11.10.2017

Kabul Tarihi: 18.10.2017

\title{
On the Fate of Ottoman Cultural Properties during the Gallipoli Campaign
}

\author{
Turan TAKAOĞLU* \\ Mithat ATABAY**
}

\begin{abstract}
$\ddot{O} z$
Bu çalışma Birinci Dünya Savaşı sırasında Çanakkale Savaşı esnasında İtilaf devletleri askeri güçlerinin Çanakkale Boğazının Trakya ve Anadolu kısımlarında kalan topraklarında bulunan askeri nitelik taşımayan mimari yapılar üzerinde yaptığ tahribatın boyutlarını irdelemeyi amaçlar. Savaş ve uyuşmazlık zamanlarında kimlik, inanç ve ortak hafiza gibi milli kimliği temsil eden kültür varlıkları veya sivil ve mimari öğeler düşman güçler tarafindan çoğu zaman hep bilerek hedef alındiğı durumlar olmuştur. Kale ve benzeri askeri yapılar savaş zamanında canlı hedefler olduğundan dolayı savaş gemileri ve uçakların her zaman hedefleri doğru bir şekilde vuramadığından dolayı söz konusu askeri yapılar etrafinda bulunan yapılara kasti olmayan hasarlar da verilmiş olduğu durumlar vardır. Ancak, 1915 yılına ait bazı tarihi Osmanlı belgeleri Çanakkale Savaşı sırasında Itilaf devletlerinin havadan veya denizden yaptı̆̆ bombardimanlar sonucu bazı askeri karakteri olmayan Osmanlı kültür varlıklarının belirli oranda tahrip olduğu ve hatta bu tahribatların bazılarının gereksiz yere bilinçli olarak yapıldiğ dikkat çeker. Bunun sonucu olarak Çanakkale Savaşı sırasında ve hemen öncesinde askeri yapıları barındıran ve Çanakkale Boğazı'nın güney kıyısı yerleşimlerinden Çanakkale (Çanak, Kale-i Sultaniye), Erenköy ve Kumkale gibi yerleşimler yanında Gelibolu Yarımadası'nda bulunan Seddülbahir ve Bolayır konumları gereği sivil ve dini mimarilerinde tahribat yaşamışlardır. Gelibolu Yarımadası bünyesinde stratejik konumlarda bulunan Maydos ve Krtihia köyleri de Itilaf devletlerinin hedef haline geldiğinden buralarda bulunan bazl sivil ve dini mimari yapılarda tahribat yaşanmıştır. Osmanlı kültür mirasının korunmasına yönelik Türklerce alınan bazı önlemlerin de olması da bu bağlamda dikkat çekici bir durumdur. Tarihi belgelerin fotoğrafik belgeler ışığında irdelenmesi İtilaf Devletleri güçlerinin iyi hesaplanmamış olan ve askeri nitelikte olmayan bir çok yapıda tahribata neden olan deniz ve hava saldırılarının Çanakkale Savaşı sırasında insaniyete ve imza atılan
\end{abstract}

* Turan TAKAOĞLU, Prof. Dr., Çanakkale Onsekiz Mart University, Department of Archaeology, e-mail: takaoglu@comu.edu.tr

** Mithat ATABAY, Yrd. Doç. Çanakkale Onsekiz Mart University, Department of History, e-mail: matabay@comu.edu.tr 
uluslararası antlaşmalara aykırı bir biçimde ölçülerin ötesine geçtiğini düşündürür.

Anahtar Kelimeler: Çanakkale Savaşı, 1915, sivil ve dini mimari, tahribat, bombardıman

\section{Abstract}

This paper aims to evaluate the extent of damage caused to Ottoman cultural properties by the Allied forces during the Gallipoli Campaign, which took place during the First World War both on the Thracian and Asian sides of the Dardanelles. In times of war or armed conflict, cultural properties representing the identity, faith, and shared values that help to reinforce a sense of national identity often become inadvertent targets by opposing forces. There might have been cases in which Ottoman cultural properties located around military such as fortresses and artilleries that were viable targets in wartime were damaged unintentionally. However, certain Ottoman historical sources dating to 1915 seemingly attest to deliberate destruction of Ottoman buildings of non-military character by bombardments from the battleships and aircraft of the Allied Forces. As a result, certain Ottoman civilian and religious structures located around the military installations at Çanakkale (Chanak, Kale-i Sultaniye), Erenköy, and Kumkale on the southern shores of the Dardanelles as well as Seddülbahir and Bolaytr on the Gallipoli Peninsula witnessed damage because of their location. Such villages as Maydos and Krithia located at strategic locations in the Gallipoli Peninsula also became targets of the Allied forces. This paper in this context aims to determine the degree to which Ottoman cultural properties were affected by direct and indirect gun-fire and bombardment during the Gallipoli Campaign. In addition, several examples of Turkish efforts to protect the cultural properties from being harmed by bombardment from the Anglo-French Allies are also briefly outlined here. The evaluation of historical sources in relation to photographic data demonstrates that the naval and aerial assaults resulting in the damage to the Ottoman cultural properties were beyond the limits during the Gallipoli Campaign, which could not be explained in human terms and international conventions.

Key words: Gallipoli Campaign, 1915, non-military structures, damage, bombardment 
The Gallipoli Campaign that took place between 25th April 1915 and 9th January 1916 was undoubtedly one of the most heroic battles ever fought by the Turks as it was a unexpected military disaster with heavy casualties to the Allied Forces who intended both to knock the Ottoman Empire out of the war and to re-open the sea route between Europe and Russia by seizing Constantinople during the First World War. Turkish casualties were also enormous, exceeding the Allies in number.

The Gallipoli Campaign was first initiated with naval operations and raiding parties by Anglo-French ships in the months of February and March 1915 on both sides of the Dardanelles Strait, followed by a full-scale landings on the Gallipoli Peninsula by British and French troops including the Australian and New Zealand Army Corps (ANZAC) on April 25. The last naval attempt to force a passage up the Dardanelles on March 18 had ended with the sinking of three battleships of the Allied Forces, while the land operations that succeeded the naval failure, beginning on April 25, also did not favor of the British, French and ANZAC troops, who met fierce opposition. The purpose of this military operation was basically to assist the fleet in forcing the Dardanelles strait by taking from the rear the Ottoman fortresses located on the European side of the Strait and to obtain a vantage point from which fortresses on the Asiatic side could be dominated. Despite the fact that the Gallipoli Campaign ended with heavy casualties on both sides, the most important outcome of the war was the sense of collective consciousness and patriotism that it created among the Turks at the onset of the creation of the modern Turkish Republic. The Gallipoli Campaign also became a national narrative for Australia and New Zealand (Sagona et al. 2016).

Although the literature on various aspects of this historical event yearly increases, the long-neglected issue of how the buildings of non-military character of the Ottoman Empire around the Dardanelles were affected by this campaign has unfortunately not been examined. A work by Ahmet Esenkaya (2004) represents the first through study of the inhumane acts that were committed by the Allied Forces during the Gallipoli Campaign despite that fact that they were among the signatory countries of the international conventions related to the times of war. This valuable work, bringing together information derived from a series of documents from the Ottoman archives, Ottoman newspapers, and the accounts of Ottoman military officers, demonstrates that the Allied forces carelessly assaulted the locations that had no military character at all both during and at the onset of the Gallipoli Campaign for some reasons.

This paper in this context aims to examine the extent of damage caused to Ottoman non-military buildings by the Allied forces during the Gallipoli Campaign. The Gallipoli Campaign indeed witnessed damage to numerous Ottoman non-military structures by aerial and naval bombardments, despite fact that the Ottoman Empire was one of the signatories of three different Hague conventions signed in 1899 and 1907 along with Britain and France. The earliest Article 27 of the Hague Convention 
signed on 29 July 1899 . This article rules that 1: "In sieges and bombardments all necessary steps should be taken to spare as far as possible edifices devoted to religion, art, science, and charity ... provided they are not being used at the time for military purposes. It is the duty of the besieged to indicate the presence of such buildings or places by distinctive and visible signs, which shall be notified to the enemy beforehand." Article 27 of the Hague convention (IV) signed on 18th October in 1907 added historic monuments, hospitals, and places where the sick and wounded are collected. ${ }^{2}$

Most important of all, Article 5 of the 1907 Hague Convention (IX) concerning Bombardment by Naval Forces in Times of War provides that ${ }^{3}$ : In bombardments by naval forces all the necessary measures must be taken by the commander to spare as far as possible sacred edifices, buildings used for artistic, scientific or charitable purposes, ... on the understanding that they are not used at the same time for military purposes. It is the duty of the inhabitants to indicate such monuments, edifices or places by visible signs, which shall consist of large, stiff rectangular panels divided diagonally into two colored triangular portions, the upper portion black, the lower portion white. The stripes observed on the minarets of several mosques located on both sides of the Dardanelles Strait, including Çanakkale town and the village of Kilitbahir, might have been derived either from this regulation related to the protection of religious edifices or simply to disguise their location during the Gallipoli Campaign (Fig. 1).

The best example to demonstrate the violation of the Hague Convention by naval forces of the Allies is probably the bombardment of the tomb of Şehzâde Süleyman Paşa at the village of Bolayır. This tomb, undoubtedly among the most significant heritages of the Ottoman Empire, was damaged during the bombardments that took place at the onset of the Gallipoli Campaign. Şehzâde Süleyman Paşa, the eldest son of Sultan Orhan, was a famous military commander who was the first to gain control over territory in Europe, a conquest that secured the expansion of the Ottoman Empire into Europe. Because this historically important figure unfortunately died here as a result of injuries sustained from falling from his horse, he was buried at Bolayır instead of Bursa, then the capital city of the Ottoman Empire, in order to symbolize his merit as being significant in Ottoman history (Uzunçarşılı 1988: 158).

1 Regulations concerning the Laws and Customs of War on Land, annexed to Convention (II) with respect to the Laws and customs of War on Land, The Hague, 29 July 1899, Article 27.

2 Regulations concerning the Laws and Customs of War on Land, annexed to Convention (IV) respecting to

The Laws and Customs of War on Land, The Hague, 18 October 1907, Article 27.

3 Hague Convention (IX) concerning Bombardment by Naval Forces in Times of War, The Hague, 18 October

1907, Article 5 
The tomb of Şehzâde Süleyman Paşa was evidently targeted by the British battleship HMS Queen Elizabeth on March 29th, 1915 (Fig. 2). This battleship, stationed outside the straits, first began indirect bombardment of fortresses located along the Dardanelles Strait starting on March 5th, 1915. The long-range bombardment by the HMS Queen Elizabeth was reportedly one of the primary actions in the Naval Plan of the Gallipoli Campaign (Churchill 1931: 389). An Ottoman document of 20th April 1915 written by von Bronsart von Schellendorf, the German Assistant Chief of the Ottoman General Staff, to the office of the Ministry of Foreign Affairs (Hariciye Nezâreti) of the Ottoman Empire provides us with details regarding this action undertaken against the Hague conventions on the protection of cultural properties, signed both by the Ottomans and the British before the war (Fig. 3). ${ }^{4}$ Here, Bronsart asks the Ministry of Foreign Affairs to harshly condemn this British action that damaged the tomb of Şehzâde Süleyman Paşa. Bronsart views the bombardment of the tomb as a deliberate action because Şehzâde Süleyman Paşa was a symbolic figure who played an important role in Ottoman history. By blaming the British as untrustworthy with no limits, Bronsart also states in this letter that the destruction of the tomb at Bolayir could not be explained in terms of the values of humanity and civilization. A photograph taken on 1915 show damage done to the minaret of Şehzâde Süleyman Paşa Mosque located near the tomb by a 15-inch shell fired by the HMS Queen Elizabeth or shrapnel from this shell (Fig. 4). ${ }^{5}$

Another monument damaged by gun-fire at Bolayir was the tomb of the famous Turkish intellectual, writer and poet Namik Kemal (1840-1888), which is located near the tomb and mosque of Şehzade Süleyman Paşa. Namık Kemal, who deeply influenced the formation of the Turkish national identify, was buried at Bolayır following his death on the island of Sakı/Chios. Although he was initially buried in the cemetery (hazire) of a mosque on the island, his remains were transported to Bolayir and re-buried there in the same year by the order of Ottoman Sultan Abdulhamid II. Namık Kemal wished to be buried alongside Şehzade Süleyman Paşa after being impressed by this place during a visit with his close friend Ebüzziya Tevfik when working at Gallipoli (Sütçü 213: 1432). The plan of his tomb, represented by a sarcophagus roofed by a dome rising above eight marble columns, was designed by Tevfik Fikret. A photo published in the third issue of Harp Mecmuası in 1915, showing the visit of a delegation of Ottoman literary men (Heyet-i Edebiye) to the Namik Kemal' tomb

4 BOA, HR. SYS, 2098/10. See Osmanlı Belgelerinde Çanakkale Muharebeleri I (Ankara 2005). T.C. Başbakanlık Devlet Arşivleri Genel Müdürlüğü Osmanlı Arşivi Daire Başkanlığı Yayın no. 71); For correspondence of the Ministry of Foreign Affairs of the Ottoman Empire following this letter, see also BOA, HR. SYS, 2099/11. Osmanl Belgelerinde Çanakkale Muharebeleri II (Ankara 2005). T.C. Başbakanlık Devlet Arşivleri Genel Müdürlüğü Osmanlı Arşivi Daire Başkanlığı Yayın no. 73).

5 Harp Mecmuası 5 (1915) 76 
after damage caused by gun-fire at Bolayır, clearly proves that the roof of his grave totally collapsed at that time. 6

Besides the naval bombardment of Bolayır, the villages of Maydos and Krithia (Kirte) also suffered during the war. Maydos and Krithia were dominated by Greek populations from as early as the fifteenth century during the reign of the Ottoman Sultan Mehmed the Conqueror (1451-1481) (Sezgin 1998: 167-172). These villages continued to be occupied mainly by the Greeks of the Ottoman Empire until their evacuation just before the beginning of the Gallipoli Campaign in 1915. Of these two villages, Maydos witnessed aerial bombing from British aircraft on 23th April, resulting in damage to numerous buildings of non-military character and the death of 29 people, 17 being Greek civilians and 12 Turkish soldiers (Esenkaya 204: 61).7 The Allied forces evidently continued to demolish Maydos after this event, since the British fleet shelled the town on 29 April, 8 The fire caused by the shelling set the town on fire, which lasted until the following day, causing massive damage and loss of life. A photograph taken from the Hagios Demetrios Hill, the highest point of the town, clearly shows this damage on the buildings located on the southern part of Maydos right after the war (Fig. 6).

As is mentioned above, the town of Maydos was one of the oldest settlements in the Gallipoli Peninsula populated mainly by a Greek community as early as the second half of the fifteenth century when the region came under the Ottoman control. The Ottoman government exempted the Greek populations of Maydos from paying taxes in return for their services as oarsmen in the Ottoman navy. The community of Maydos later turned to be good sailors who played a major role in seafaring within the Dardanelles and the entire Sea of Marmara. In the nineteenth century, this prosperous Ottoman town was noted with a high number of Churches, including Aghios Demetrios, Aghios Ioannis, Panagia Faneromeni, Pammegiston Taxiarchon, and Aghios Spyridon. Several 19th century Greek historiographies lists these Churches that dominated the landscape of Maydos. Chrysostomos Papadopoulos, a native of Maydos who became Archbishop of Athens and Primate of the Church of Greece in 1923, is one of them who described the religious life and related buildings in the town in his days (Papadopoulos 1890: 30). Besides the work of Papadopoulos, Ta Thrakika (On the Thracians) is another valuable work composed by Eustratios Drakos, who provides a very detailed information about the settlements of the Gallipoli Peninsula

$6 \quad$ Harp Mecmuası 3 (1915) 42.

7 Birinci Dünya Harbi'nde Türk Harbi: Çanakkale Cephesi Harekâtı ( Haziran 1914-24 Nisan 1915) , V. Cilt, I. Kitap, Genelkurmay Basımevi, (Ankara 1993), 253; Çanakkale Deniz Savaşları Günlüğü (1914-1922). Deniz Mayınları Grup Komutanı Binbaşı Nazmi Bey (Çanakkale Deniz Müzesi Komutanlığı 2004), 59; “Bir Müşahidin Beyanı” İkdam Gazetesi (May 1st, 1915); "Alçakça bir Tecavüz ve Netayici" İkdam Gazetesi (May 18th, 1915);

8 Çanakkale Deniz Savaşları (Çanakkale Boğaz Komutanlığı 2008), 56, 201. 
inhabited by the Greek communities of the Ottoman Empire (Drakos 1892). Apostolos Sitaras, a doctor born in Maydos in 1877 and left his hometown in 1922 following the population exchange ruled by the Lausanne Treaty, also has an excellent narrative of his native town. His work entitled Madytos, City of the Thracian Chersonessus on the Hellespont (in Greek), which was published after his death in 1949 by his compatriots, has so far been the most complete account ever written on Maydos (Sitaras 1971). Most of these religious buildings belonging to the Greeks community of Ottoman Maydos were damaged to a great extent by naval and aerial assaults of the Allied forces. Those religious buildings that were not hit by gun fires at Maydos were lost because of fire that began at the town following these assaults.

Similar to Maydos, the village of Krithia, populated by Greeks since as early as 1475 according to Ottoman historical sources, was one of the oldest settlements on the Gallipoli Peninsula along with other villages inhabited by the Turks, including Küçük Anafarta, Büyük Anafarta, Küçük Behramlı and Büyük Behramlı (Sezgin 1988: 168, Tablo 34). The village was evacuated at the onset of the Gallipoli Campaign. Several major battles were fought near Krithia during the Gallipoli Campaign. The village was the main objective on the first day of the landings, 25 April 1915. Over the following months, British and French troops, who had landed at the tip of the Gallipoli Peninsula, made several attempts to capture the village. Krithia was never reached; the Turkish defenders successfully repulsed every assault. Thanks to numerous accounts of the soldiers taking part in the fight for Krithia, we have a clear picture of the extent of the damage at Krithia. British soldier Hary Askin is one of those who provides a vivid picture of the village during the Gallipoli campaign: "It was possible to see what a mass of ruins the village was. Not a single complete house remained, some being just heaps of charred wood and stone, others just mere skeletons of houses. The line of windmills was badly battered and I should imagine it most unhealthy for the Turks in occupation of the place." A photograph taken a year after the war in 1916 verifies the accounts found in diaries of soldiers of the Allied Forces (Fig. 7). The Kimisis tis Theotokou Greek Church at this already abandoned village was apparently damaged by artillery fires during the series of battles involving land operations, in which the seizure of Krithia was considered vital. The church clearly became of a victim of gun fires during after the land operations began.

The fate of the Seddülbahir fortress, which is situated on the tip of the Gallipoli Peninsula, was far more severe than that of Krithia. The Seddülbahir fortress was built in 1659 by Hatice Sultan during the service of the Ottoman Grand Vizier Köprülü Mehmet Pasha, who was one of the most influential figures in the history of the Ottoman Empire. Due to its strategic location at the mouth of the Dardanelles, the fortress and the village around it were bombarded a number of times by the warships of the Allied Forces. The amphibious landings near Seddülbahir were part of the plan to capture the Gallipoli Peninsula by the British and French forces on 25 April 1915. Several non-military structures were damaged by these naval assaults, both on this day and before the land operations began. A mosque (Eski Cami) and a 
bath are among the structures that were hit by artillery fires due to their close location to the Seddülbahir fortress.

Ottoman religious buildings in the settlements located on the southern shores of the Dardanelles also witnessed damage during and prior to March 18, 1915 during the Gallipoli Campaign. Such townships as Çanakkale (Chanak, Kale-i Sultaniye), Erenköy and Kumkale became targets of the warships of the Allied Forces. Useful information regarding the damage of religious buildings of the Turkish and Greek populations of the Ottoman Empire can be found in certain German diaries and accounts of 1915 and 1916. For instance, the war diary of Major Erich R. Prigge, a German officer who served as aide-de-camp to Liman von Sanders between 1914 and 1918, contains details regarding the damage of religious buildings in Çanakkale during the Gallipoli Campaign. Prigge is best-known as the first German who wrote down his experiences related to the Gallipoli Campaign, which appeared under the title of Der Kampf um die Dardanellen in 1916. Major Prigge describes the damage to one particular religious building after the bombardment as follows (Prigge 1916): "Nothing near the harbor shows the rage of war. The view inside the city is undoubtedly different. All the line of houses lay burnt. A hodja with a white skullcap on top of his head, showing his religious position in the mosque, sadly sits in front of the demolished entrance of a mosque that has a roof blown away by a gunfire from a British battleship." This account might have been related to the April 30th bombardment by the long-range bombardment by the HMS Queen Elizabeth stationed behind the Gallipoli Peninsula that devastated most parts of the Çanakkale town (Fig. 8)

Paul Schweder, who visited the region at the height of the Gallipoli Campaign as a war correspondent working for the Istanbul-based German daily newspaper Ottomanischer Lloyd, also notes the ruinous state of certain religious buildings that witnessed naval assaults from the battleships of the Allied Force. Schweder (1916: 209) describes how the charming and harmless village of Erenköy on the slopes of a hill overlooking the Dardanelles was reduced completely to ruins on March 7. Schweder clearly notes how the lavish Greek monastery of Erenköy fell into ruin: "What from the valley seemed to be a charming, Greek village, is really a ruin. In the previous years, the English and French fleets had organized a formal sport shooting at the unfortunate Greek establishment, and had not spared a single house from the sumptuous monastery and municipality buildings down to the poorest huts." Here it must be mentioned that Erenköy became a deliberate target of the Allied battleships because an artillery that was stationed here to protect the Dardanelles against the threats coming from the sea.

Kumkale, located on the Asian side of the Dardanelles, is another village with Ottoman remains that witnessed fierce naval assaults. Kumkale's fortress was first built at the mouth of the River Karamenderes at the same time as Seddülbahir fortress on the tip of the Gallipoli Peninsula, built in 1657 to secure the Aegean entrance to the strait against the Venetians by Hatice Turhan Sultan, mother of the Ottoman sultan, Mehmed IV. A village settlement subsequently developed around the fortress, mainly by the families of the soldiers who served in the fortress at the beginning (Thys-Şe- 
nocak 2007). The population of Kumkale village was around 600 during the eighteenth and nineteenth centuries (Hobhouse 1817: 143). Ottoman structures built around Kumkale fortress, including a mosque, a fountain, several windmills, and a bath, were also damaged by the bombardments (Fig. 9).

As examples of industrial/cultural heritage, windmills with a long history in the region were the most unfortunate non-military Ottoman buildings to suffer during the Gallipoli Campaign, because they were always targeted by British naval gunners during the bombardments. There are quite a number of diaries of the Allied troops that all mention the demolishing of windmills under heavy fire. Numerous windmills located at settlements such as Kumkale, Yenişehir, Seddülbahir, Maydos, and Krithia were seriously damaged by gun fires. These windmills had been working until they were evacuated during the naval operations during the Gallipoli Campaign in 1915. The story of the demolishment of Kumkale and Yenişehir located nearby is frequently repeated in the literature. Both British and French forces bombarded Kumkale for a number of times in 1915. The fiercest assault took place on February 25, 1915 when the batteries at Kumkale and Yenişehir became targets for Allied battleships of the Allied forces. Because guns were frequently fired by the Ottoman Turkish soldiers from the inside of the windmills, they became targets for the battleships of the Allied forces. Thus, all of the windmills decorating the side of the Kumkale fortress and ridge of Yenişehir (Gavurköy) Village nearby fell into ruins mainly in the attack of April $25^{\text {th }}$ of 1915 . One of the accounts of this incident was narrated by J. Corbett (1921: 164): "The landing took place at 2,30 at the pier, just east of the ruined fort, undisturbed. Advancing at once thorough the village, the party reached the cemetery beyond, without meeting any opposition. Here, they came under fire, and it looked as though an attack was about to be launched on them from Yeni Shehr. Still they pushed on, till the fire grew so hot that they were held up in a hollow beyond the cemetery. The worst of it seemed to be coming from some windmills on a ridge between them and Yeni Shehr. This was soon settled by the Dublin, who was so close in that by firing Luddite she had the mills in ruins in three minutes. "British Commander Worsley Gibson, who was aboard HMS Albion also reported a similar event: "...stuck to it jolly well and not until we'd sent two windmills up into the air like a pack of cards, most humorous to watch, and planted several beauties right on top of them did they retire." (McMeekin 2015: 184). It is upsetting to see that some of the windmills that served the communities of the region for over five centuries suddenly turned into the heaps of rubbles during the war because they were used by the Ottoman soldiers to defend the villages where they were located. There are also cases in which the windmills were hit by aerial bombing. A photograph taken at Maydos in 1915 shows Ottoman military officers in front of wrecked windmills, which were being operated by the Greeks of the Ottoman Empire before the Gallipoli Campaign (Fig. 10). This photograph probably dates just after the aerial bombing of April 21th or the shelling of the town by a British battleship on April 29th.

The evaluation of the extent of damage to certain well-known cultural properties of the lands that became scenes to the Gallipoli Campaign demonstrates one more 
time that the war is merciless and no limits. Even such concepts as cultural identity and religion did not play any role to reduce the damage to Ottoman cultural properties as much as possible. One may claim that because military installations were viable targets in wartime, warships of that era, and afloat on the water, were not always able to hit targets with pinpoint accuracy, resulting in unintentional damage to buildings of non-military character located around the military installments such as fortresses and artilleries. Others may also claim that the failure of some aircrafts hitting the targets with pinpoint accuracy also caused damage to cultural properties during the aerial assaults. Certain Ottoman historical sources imply that such explanations may not be satisfying all the time for the Gallipoli Campaign. The fate of Maydos full of churches of the Greek populations of the Ottoman Empire briefly outlined above is clearly a good example of this case. 


\section{References}

Aspinall-Oglander, C.

1917 Military Operations Gallipoli. London: William Heinemann Ltd.

Baker, J., G. Newlyn, N. Woolaston

2015 A Marine at Gallipoli and on the Western Front: First in Last out. The Diary of Harry Askin. South Yorkshire: Pen \& Sword Military.

Churchill, W.S.

1931 The World Crisis, 1911-1918. London: Thornton Botterworth.

Corbett, J.

1921 Naval Operations, Vol. II. London: Longman, Greens and Co.

\section{Drakos, E.I.}

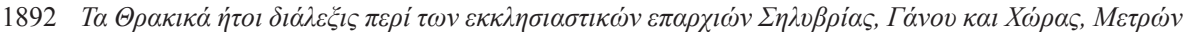

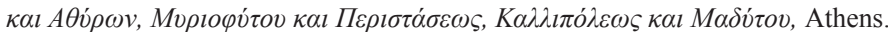

Esenkaya, A.

2006 "Çanakkale Muharebelerinde İtilaf Devletlerinin Savaş Hukukuna Aykırı Davranışları." Çanakkale Araştırmaları Türk Ylllı̆̆ 4: 51-95

Hobhouse,J.C.

1817 A Journey through Albania and other provinces of Turkey in Europe and Asia to Constantinople during the years 1809 and 1810. Vol. II. Philadelphia.

McMeekin, S.

2015 The Ottoman Endgame: War, Revolution, and the Making of the Modern Middle East, 1908-1923. New York: Penguin Books.

Papadopoulos, A. H.

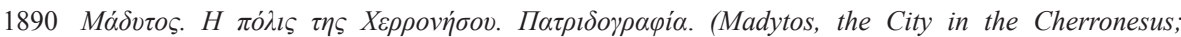
Patridography)Athens.

Prigge, E. R.

1916 Der Kampf um die Dardanellen. Weimar: Gustav Kiepenheuer.

Sagona, A., M. Atabay, C.J.Mackie, I. McGibbon, R. Reid 2016 Anzac Battlefield. A Gallipoli Landscape of War and Memory. Cambridge: Cambridge University Press.

2016 Anzac Battlefield. A Gallipoli Landscape of War and Memory. Cambridge: Cambridge University Press.

Schindler D. and J. Toman

1988 The Laws of Armed Conflicts. Dordrecht: Martinus Nihjoff Publisher.

Schweder, P.

1916 Im Turkischen Hauptquartier. Leipzig: Hesse \& Becker

Sezgin, İ.

1998 XV. ve XVI. Astrlarda Gelibolu Kazasinın Sosyal ve Ekonomik Tarihi. Marmara Üniversitesi, Yayınlanmamış Doktora Tezi.

Sitaras, A.E.

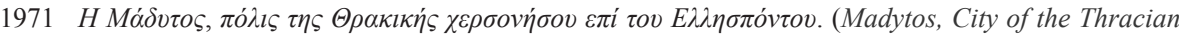
Chersonessus on the Hellespont). Athens. 
Sütçü, T.

2003 “Namık Kemal'in Yaşamında ve Eserlerinde Gelibolu.” Turkish Studies 8/13: 1411-1426.

Takaoğlu, T.

2016 Çanakkale Kültürel Mirasında Yel Değirmenleri. İstanbul: Ege Yayınevi.

Thys-Şenocak, L.

2007 Ottoman Women Builders: Architectural Patronage of Hadice Turhan Sultan. Florence: Taylor \& Francis

Uzunçarşı11, İ.H.

1988 Osmanlı Tarihi, Cilt I. Osmanlı Tarihi Anadolu Selçukluları ve Anadolu Beylikleri hakkında Bir Mukaddime Ile Osmanlı Devleti'nin Kuruluşundan İstanbul'un Fethine Kadar. Ankara: Türk Tarih Kurumu. 

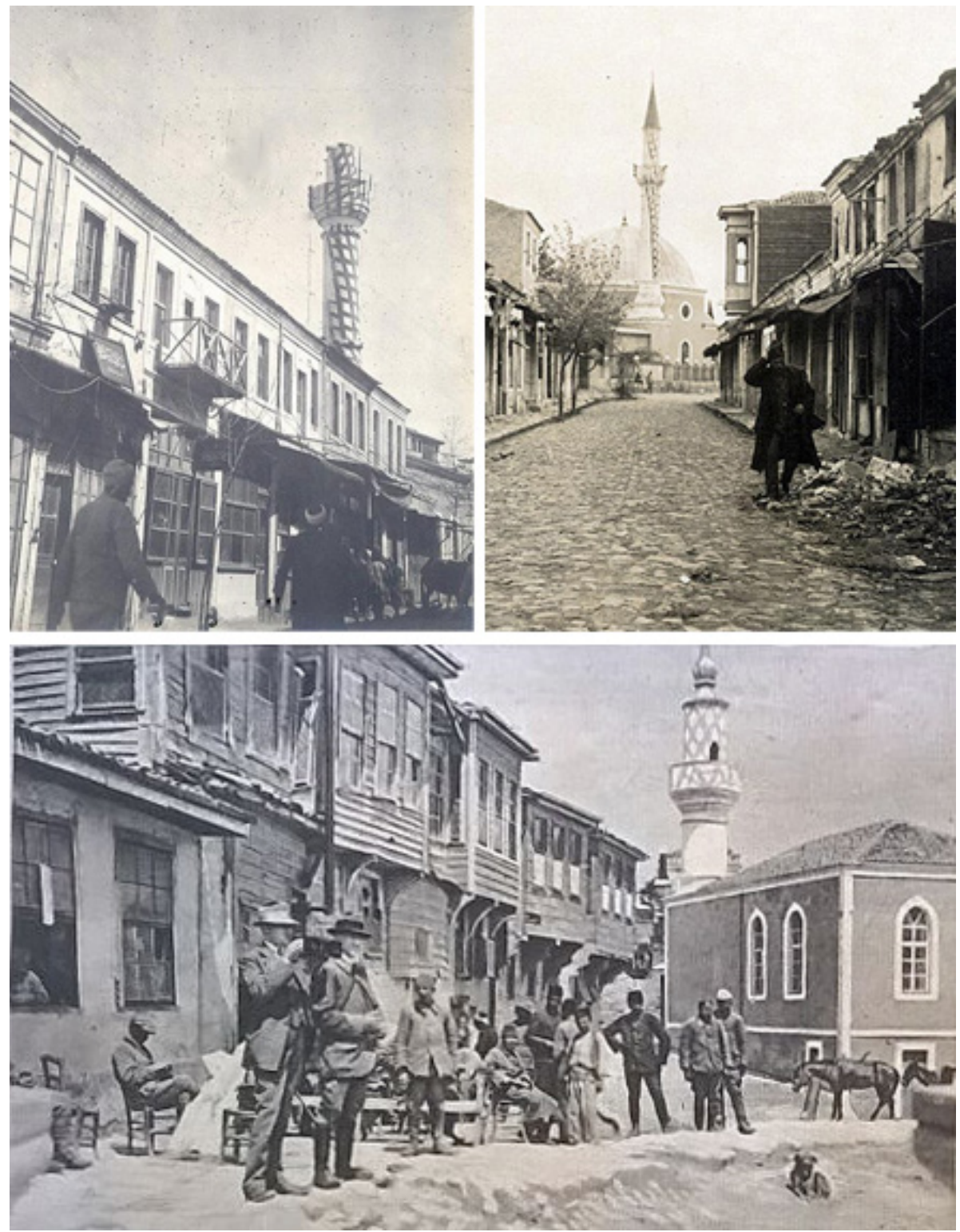

Figure 1. Three different images from 1915 all showing how the white minarets of Ottoman mosques were disguised by stripes from the naval assaults of the Anglo-French fleet during the Gallipoli Campaign: Tavil Ahmet Ağa Mosque (Yalı Cami) (upper left) and Arap İbrahim Paşa (Kurşunlu (Cami) Mosque at Çanakkale and Tabib Hasan Paşa Mosque at Kilitbahir (below). 


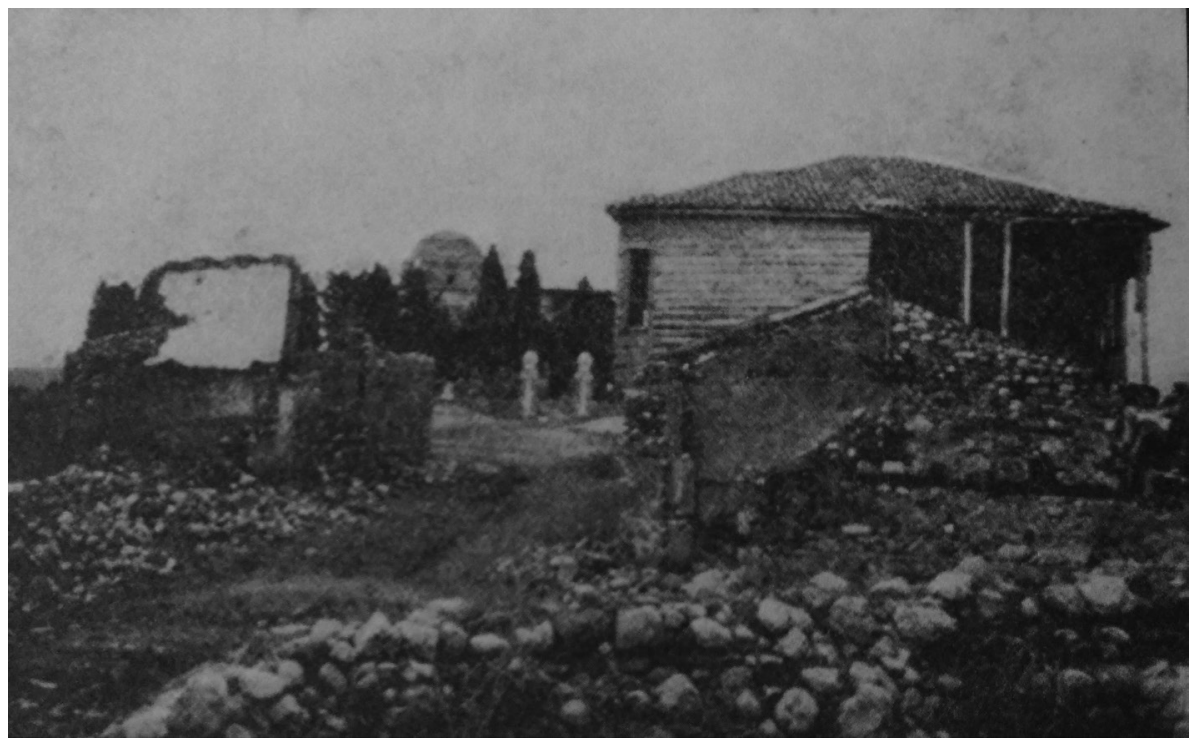

Figure 2. Tomb of Şehzâde Süleyman Paşa Mosque at Bolayır, damaged by gun-fire from the HMS Queen Elizabeth on March 29th, 1915 (Photo: Harp Mecmuası 5, 1915, 76).

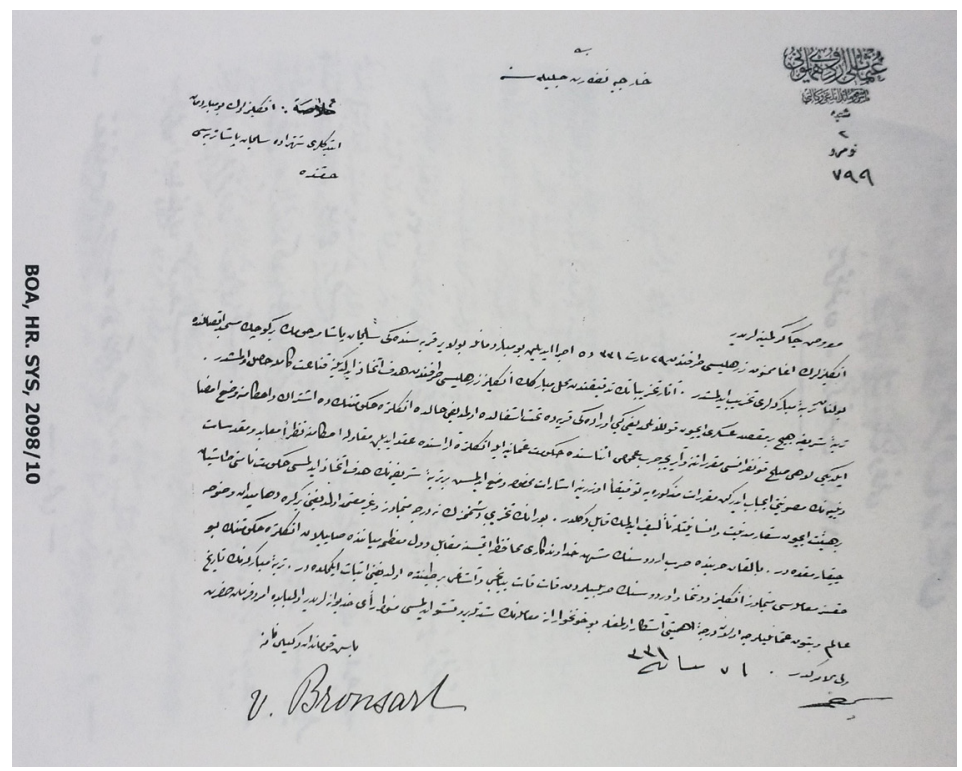

Figure 3. Letter of Bronsart regarding bombardment of tomb of Şehzâde Süleyman Paşa at Bolayır (BO, HR. SYS, 2098/10) 


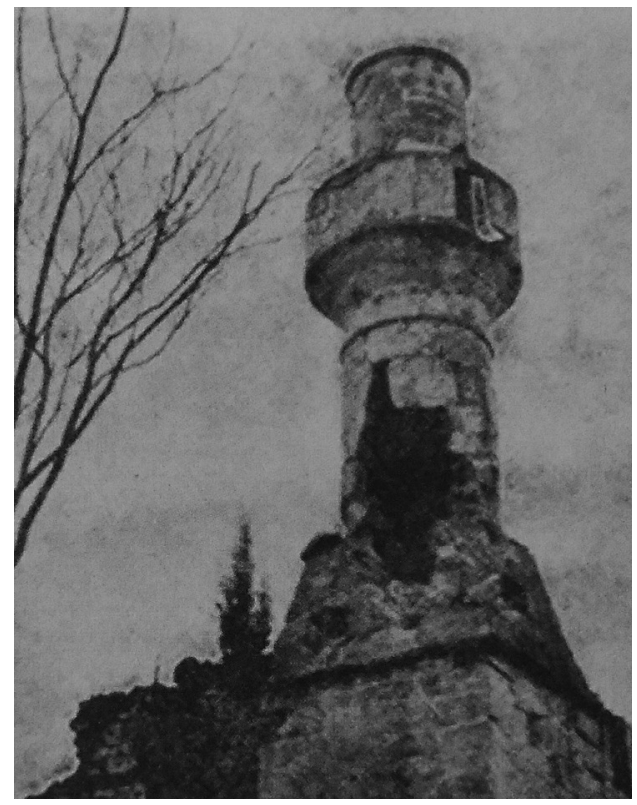

Figure 4. Minaret of Şehzâde Süleyman Paşa Mosque at Bolayır, damaged by gun-fire from HMS Queen Elizabeth on March 29th, 1915 (Photo: Harp Mecmuası 5, 1915, 76).

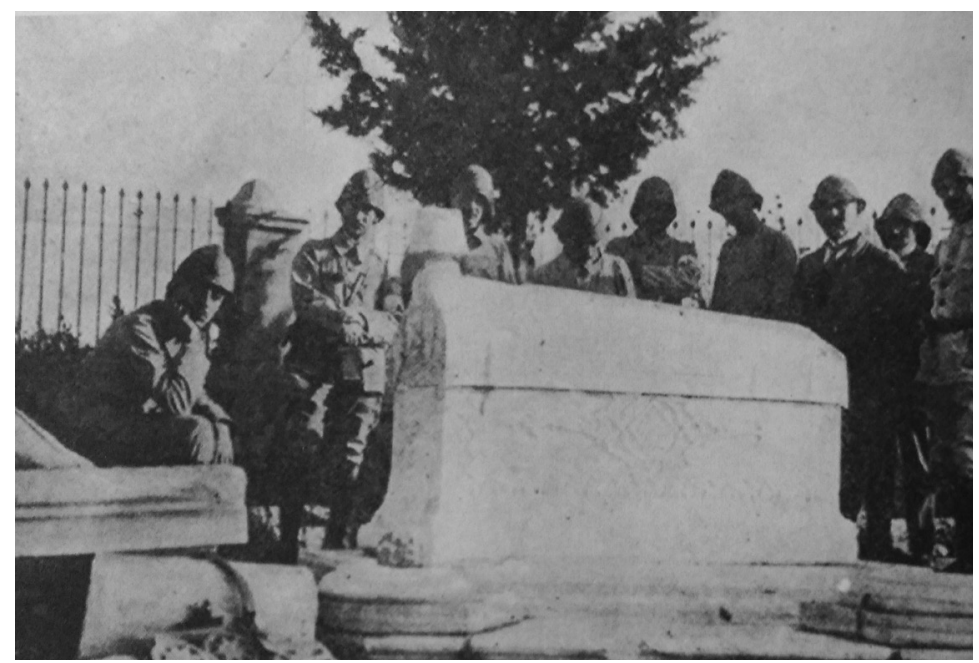

Figure 5. Ottoman delegation (Heyet-i Edebiye) visiting Namık Kemal's tomb at Bolayır, which was damaged by naval assault from the warships of the Allied Forces (Photo: Harp Mecmuası 3, 1915, 42). 


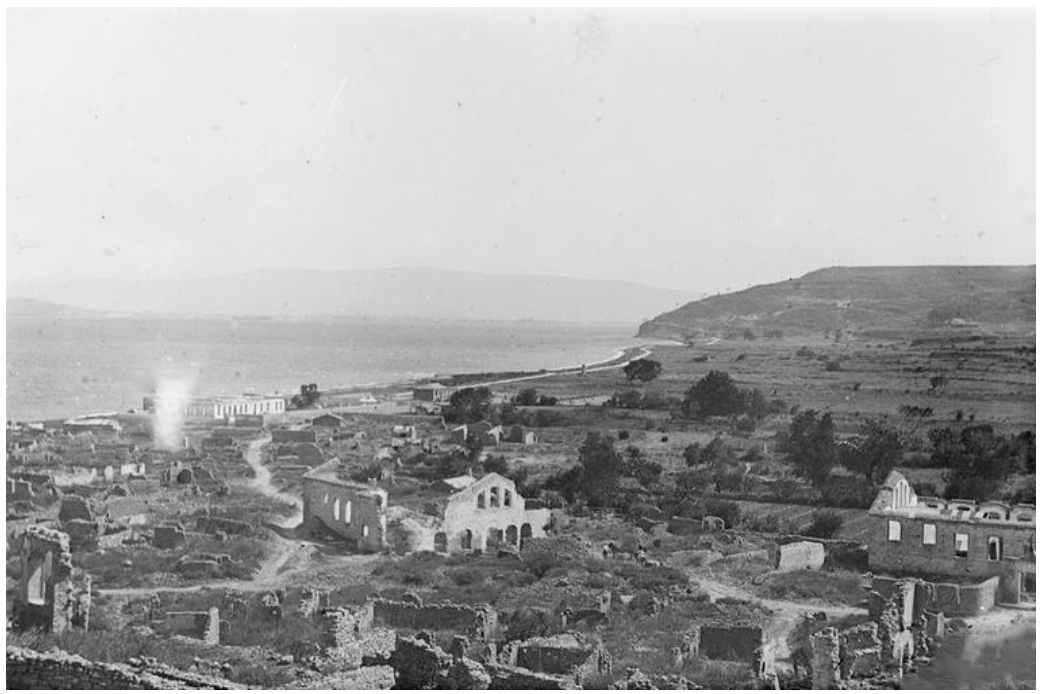

Figure 6. View of southern sector of Maydos after the Gallipoli Campaign from the Church of Haghios Demetrios Hill. Note the religious and civil remains of the Greek populations of Maydos in ruins after several aerial and naval assaults starting on April 23th, 1915 (Photo: Imperial War Museum, Q 13922)

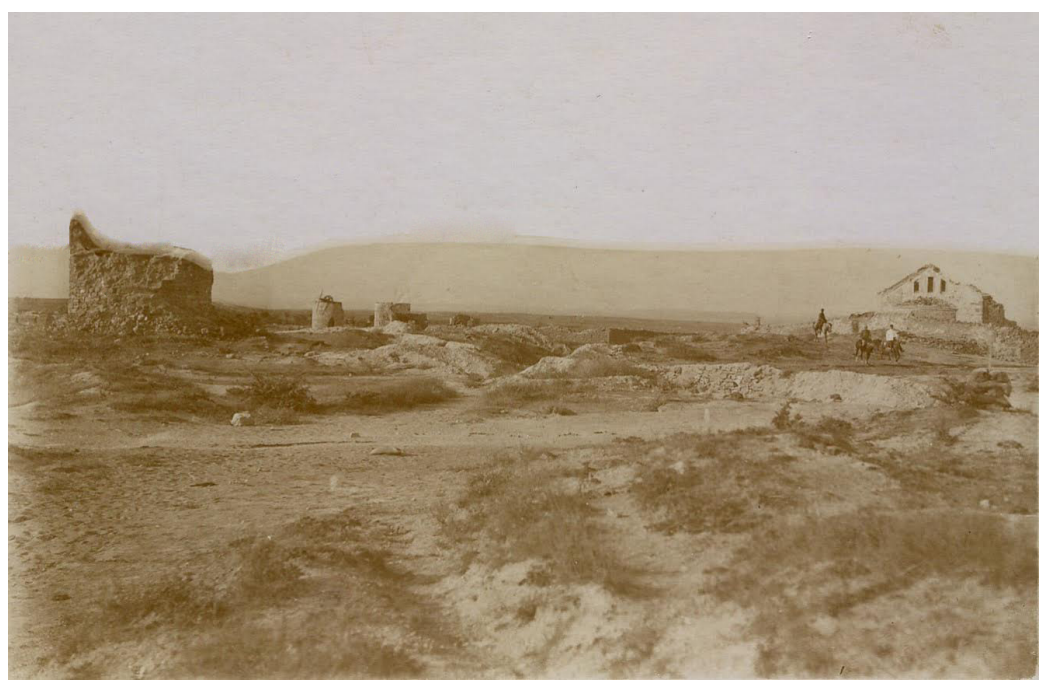

Figure 7. Photo from 1916 showing the "Kimisis tis Theotokou" Greek church at the village of Krithia opposite a line of windmills, all damaged by gun-fire during the battles of Krithia following Allied landings on April 25 during the Gallipoli Campaign.

(Photo: Courtesy of Yetkin İşcen) 


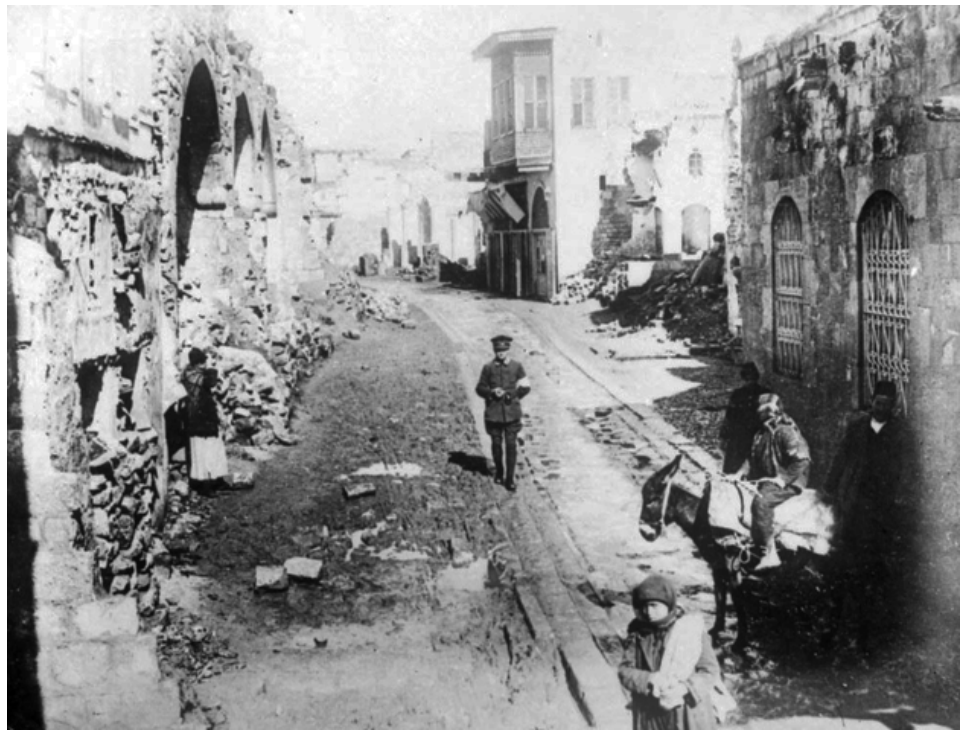

Figure 8. A street in the town of Çanakkale (Chanak, Kale-i Sultaniye) showing the damage resulting from shelling by the British battleship HMS Queen Elizabeth (Photo: Australian War Memorial H 16637).

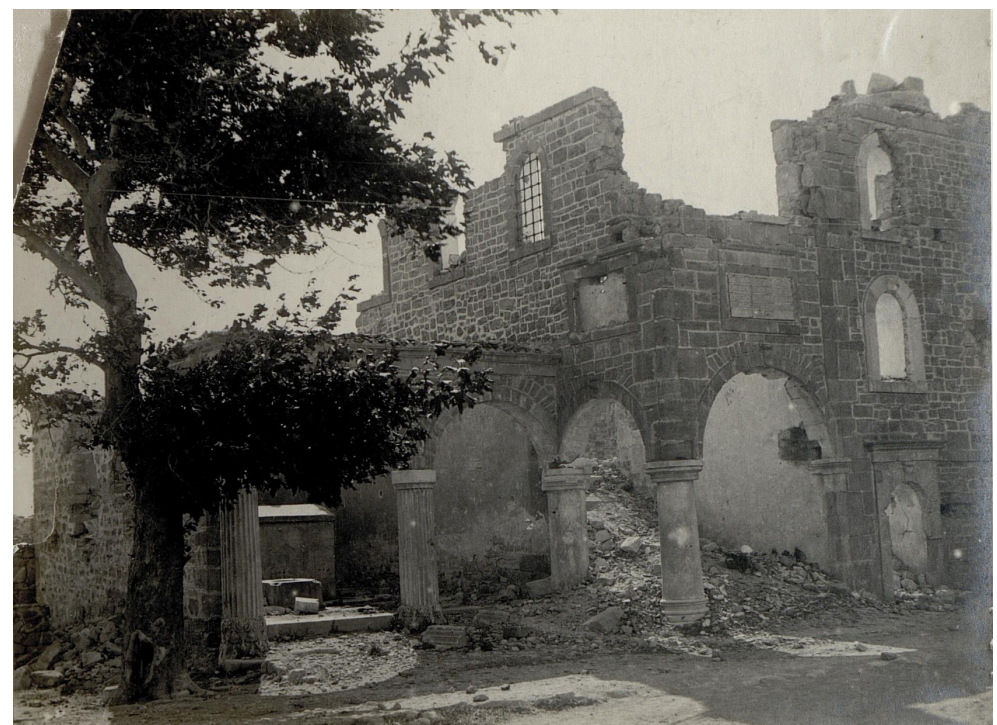

Figure 9. Ottoman Mosque at Kumkale after naval assaults from Anglo-British ships right before 18 March 1915. 


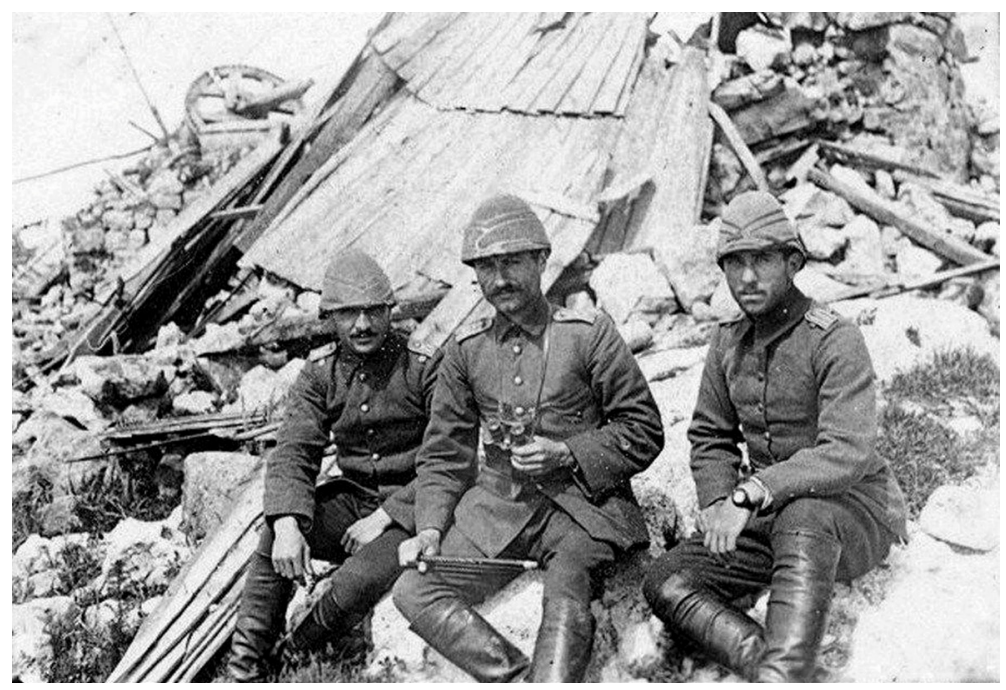

Figure 10. Photo taken in 1915 showing Turkish military officers in front of wrecked windmills mainly used by Greeks of the Ottoman Empire at that time at Maydos. The photo probably dates just after the aerial bombing of April 23th.

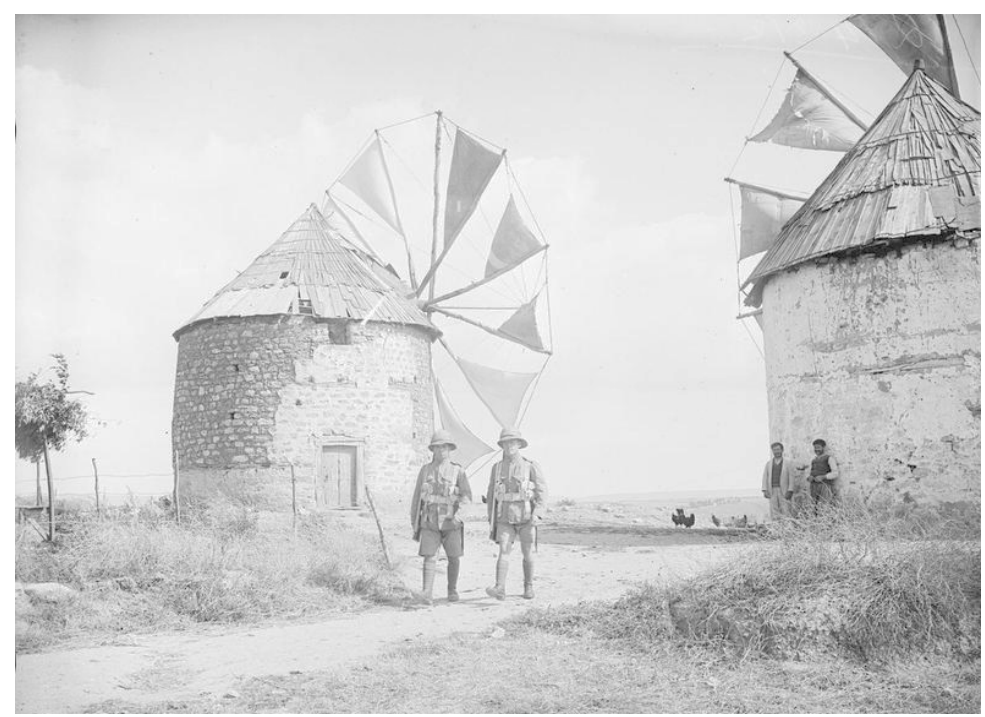

Figure 11. 1919 photo showing how the windmills looked before being frequently targeted during bombardments. The photo shows two British soldiers from the 9th Battalion on patrol in Gallipoli during the occupation (Photo: Imperial War Museum Q 14312, (C) Takaoğlu) 